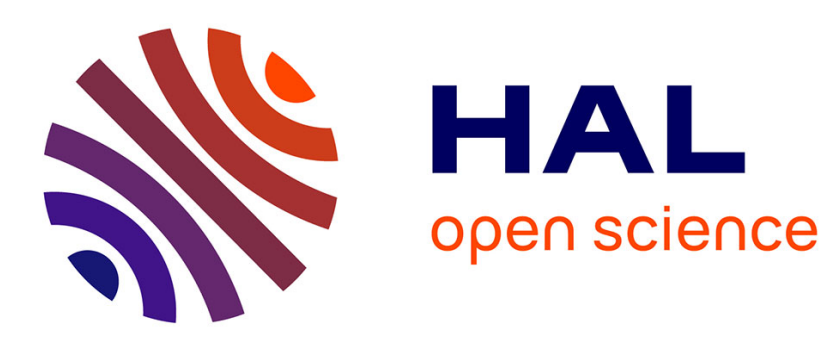

\title{
Co-opting Science: A preliminary study of how students invoke science in value-laden discussions
}

\author{
Jan Alexis Nielsen
}

\section{To cite this version:}

Jan Alexis Nielsen. Co-opting Science: A preliminary study of how students invoke science in valueladen discussions. International Journal of Science Education, 2011, 10.1080/09500693.2011.572305 . hal-00712369

\section{HAL Id: hal-00712369 https://hal.science/hal-00712369}

Submitted on 27 Jun 2012

HAL is a multi-disciplinary open access archive for the deposit and dissemination of scientific research documents, whether they are published or not. The documents may come from teaching and research institutions in France or abroad, or from public or private research centers.
L'archive ouverte pluridisciplinaire HAL, est destinée au dépôt et à la diffusion de documents scientifiques de niveau recherche, publiés ou non, émanant des établissements d'enseignement et de recherche français ou étrangers, des laboratoires publics ou privés. 


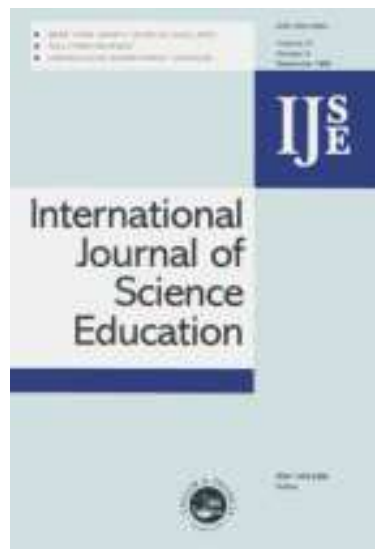

\section{Co-opting Science: A preliminary study of how students invoke science in value-laden discussions}

\begin{tabular}{|r|l|}
\hline Journal: & International Journal of Science Education \\
\hline Manuscript ID: & TSED-2011-0017-A.R1 \\
\hline Manuscript Type: & Research Paper \\
\hline Keywords : & science education, argumentation, discourse \\
\hline Keywords (user): & socio-scientific issues \\
\hline
\end{tabular}

\section{SCHOLARONE ${ }^{m}$ Manuscripts}




\section{Co-opting Science: A preliminary study of how students invoke science in value-laden discussions}

Letting students deliberate on socio-scientific issues is a tricky affair. It is yet unclear how to assess whether, or even support that, students weave science facts into value-laden socio-scientific deliberations without committing the naturalistic fallacy of deducing 'ought' from 'is'. As a preliminary step, this study investigated how Danish upper secondary biology students actually interwove science facts and values in socio-scientific discussions. In particular, the focus was the argumentative effects of different ways of blurring the factvalue distinction. The data consisted of the transcriptions of three 45-60-minute discussions among 4-5 students about whether human gene therapy should be allowed. The data was analysed from a normative pragmatics perspective with a focus on how the students designed and elicited messages to influence the decisions of others. It was found that the students regularly co-opted science to make it appear that their evaluative claims were more solidly supported than those of their opponents. Further, the students tended to co-opt science content so as to redefine what the issue or object of contention should be. The findings suggest that assessment of whether students properly used correct science facts in socio-scientific learning activities is very difficult. From the perspective of teachers this means that much more work needs to be done in order to sort out how the fact-value distinction should be addressed appropriately. From the perspective of researchers it means a continued negotiation of what they mean when they say that students' should become able to use science on issues from outside science.

Keywords: science education, argumentation, socio-scientific issues, fact-value distinction 


\section{Introduction}

One of the key rationales of science education is to enable future citizens to 'engage in debate and decision-making in contexts featuring scientific information' (Ryder, 2001, p. 3; see also EU-Commision, 2004; Millar \& Osborne, 1998; OECD, 2006). But the idea of weaving scientific information tightly into the fabric of societal decision-making can quickly lead to trouble: Scientific information could never by itself authorize or justify a value-decision; and decisions about societal issues tend to be just that - value-decisions. Indeed, it is a logical fallacy to derive a practical decision (about what to do) from an array of scientific factual statements (about how things are) (Hare, 1952; Nowell-Smith, 1954). Science education researchers and teachers must enable students to be reflective about the correctness of scientific information. But it is equally important that students learn to invoke such factual information correctly and distinguish it from value-claims. It is well established that science educators should pay attention to the fact-value distinction, but it is not clear how they should assess student discourse that interweaves facts and values. This paper explores how groups of students actually interwove science facts and human values in socio-scientific discussions. Based on the findings, it is argued that future attempts to assess socio-scientific discourse in this regard face fundamental challenges.

\section{Socio-scientific Issues and the Fact-value Distinction}

Issues that pertain to areas such as stem cell research, climate change, and human gene therapy are often referred to as socio-scientific issues: They have a conceptual basis in science, but they are issues within the ethical, political, and economical realm of society (Sadler \& Zeidler, 2003). It has been demonstrated that socio-scientific issues are effective devices for students to access science content (Galvão, Reis, 
Freire, \& Almeida, 2010; Zeidler, Sadler, Simmons, \& Howes, 2005), and that students can take many different stances towards such issues, which creates an incentive for students to engage in argumentation (Walker \& Zeidler, 2007). In the following, a socio-scientific issue - such as whether to allow human gene therapy (Sadler \& Zeidler, 2004) - will be treated as an issue that calls for a discussion about what to $\underline{\text { do }}$ - not merely a discussion about what is true. A socio-scientific discussion is, thus, a discussion about a proposal - not a proposition (Kock, 2009).

Socio-scientific issues present some practical challenges in the traditional science classroom. Even though science is ever more important for resolving socioscientific issues, the scientific information that many of these issues relate to is tentative at best. The sheer complexity (Ryder, 2001) and tentative nature (Millar, 1997) of the science relevant to many socio-scientific issues renders such science content difficult to transpose to the classroom. Consequently, much science education research has been devoted to how students argumentatively manage scientific knowledge claims in a sea of tentative and conflicting evidence (Kolst $\varnothing, 2001,2006$; Patronis, Potari, \& Spiliotopoulou, 1999; Sadler, 2004; Zeidler, Osborne, Erduran, Simon, \& Monk, 2006). These investigations share the outlook that the messiness of bringing societal issues into science classrooms can be harnessed through a focus on informal reasoning patterns, allowing students to 'formulate positions, and provide supporting evidence' (Sadler, 2004, p. 515). To be sure, argumentation is a key aspect of harnessing the messiness of socio-scientific issues, but a focus on how, and how well, students provide evidence for positions might be too narrow. Recall, that a position on a socio-scientific issue could never be fully justified by scientific evidence. There will always be a value-laden reason that supports the position, and such reasons are not evidence in the strictest sense. They are principles, rather, that 
arguers point to in their arguing. So, the traditional predominant focus on evidencegiving provides little understanding of how students interweave science facts (as evidence) and values in socio-scientific discussions.

In this light, the tentative nature of science is not the only reason that socioscientific issues are challenging. Socio-scientific issues accentuate the perils of the naturalistic fallacy (i.e. the logical error of deducing normative statements from purely descriptive statements), which is borne out of the distinction between facts and values. Scientific facts are the states of affairs that science has disclosed, and they can be expressed in factual statements such as '(It is a fact that) motor neurons are longer than any other human cells' (Armstrong, 1997). Values, in contrast, are principles that guide action; persons value some objects, or circumstances, more than others and they choose their action accordingly. Consequently a value-statement differs categorically from factual statements because the former has no truth-value - it is neither definitely true nor definitely false. The terms 'value-judgement' and 'evaluation' will, following Dewey (1981), refer to discursive acts in which the speaker states what she thinks ought to be valued.

The fact-value distinction has not gone unnoticed in science education. Some have argued that an emphasis on the fact-value distinction is important for the development of students' ability to critically asses s scientific knowledge claims, and that such an emphasis is needed for students to be less prone to commit the naturalistic fallacy themselves (Kolstø, 2001; Zeidler, et al., 2006). Even more important, an emphasis on the fact value distinction is central for making students aware of the balance of roles played by science facts and human values, respectively. To be sure, a decision on a socio-scientific issue is informed only if it is made against the background of scientific knowledge (e.g. Kitcher, 2010). But it is, logically 
speaking, possible to make such a decision without invoking science (Dawson, 2000; Irwin \& Wynne, 1996) and students tend to do just that (Kolstø, 2000; Lewis \& Leach, 2006; Ratcliffe, 1997; Ryder, 2001; Sadler \& Donnelly, 2006). The dilemma is this: Though science is needed, it could never be the final arbiter in a socio-scientific context. Socio-scientific teaching activities should therefore involve a negotiation of what role science should play so that it informs students' decisions without being blindly followed (Sadler \& Zeidler, 2006). The conclusion from previous research is this: If students must learn to invoke science when they deal with socio-scientific issues, then the fact-value distinction must be made explicit in the learning process (Levinson, 2007). But little has been written on how best to address the distinction.

Two notable studies have pointed to a common way that facts and values are interwoven in students' discourse. From a study on students' self-reports concerning their standpoints on a socio-scientific issue, Albe (2008) was able to conclude that when students were asked how to make a socio-scientific decision, they reduced the issue to an underlying scientific controversy and relied on science to resolve the issue. Failure to observe the fact-value distinction in this respect leads, potentially, to fallacious reasoning. Science could never be the ultimate arbiter on how people should resolve a socio-scientific issue. Lindahl (2009) similarly documented that students, when interviewed about their thoughts on genetic testing for hereditary diseases would often rely on science as a referee for deciding when and who was subject to moral considerations. He found, for example, that '[b]iological knowledge ...was often used to objectify a fetus or person, thus excluding him/her from the moral party' (Lindahl, 2009, pp. 1308-9).

These studies indicate that students do interweave science factual and evaluative statements in their arguments on socio-scientific issues, and that students 
do so in a manner that blurs the fact-value distinction. For in both studies it was found that students relied on science to determine which evaluative stance would be preferable. But the studies did not directly address how students interwove facts and values in their argumentation. It is still an open question whether there are different argumentative outcomes when students interweave science factual information and human values; and whether the interweaving can occur in different shapes and forms. Such questions must be central for future attempts to assess students' socio-scientific discourse. Also, the studies of Albe (2008) and Lindahl (2009) did not explore discussions among groups of students. This leaves open the question of how students interweave factual information and values in an attempt to autonomously manage their disagreement on socio-scientific issues. The research question of this study is therefore the following: how and for what purpose do students interweave factual and $\underline{\text { evaluative statements in group discussions about a controversial socio-scientific }}$ issue? In particular, the study aimed at exploring the argumentative effects of a number of different ways of invoking science in a value-laden discussion about human gene therapy.

\section{Argumentation}

In discussions, people manage disagreement by putting forward and responding to arguments. Therefore the concept of argumentation is central for any study that explores how students navigate facts and values in discussions. This study was different in two respects from traditional investigations of student argumentation in science education. First, many science educators have investigated student argumentation because of the idea that science can and should be taught through argumentation-activities (Driver, Newton, \& Osborne, 2000). The topical focus has so far been on how students handle the epistemological game of providing and asking for 
evidence for science knowledge claims (Aufschnaiter, Erduran, Osborne, \& Simon, 2008; Clark \& Sampson, 2007; Jimenez-Aleixandre, Rodriguez, \& Duschl, 2000; Kelly, Druker, \& Chen, 1998; Patronis, et al., 1999; Simon, 2008; Zohar \& Nemet, 2002). In contrast, this study focussed on how students use science claims in the process of negotiating non-scientific standpoints about what society should do about human gene therapy.

Second, previous investigations have largely focused on the structure of student arguments and relied heavily on Toulmin's (1958) model of argumentation patterns in their analyses. The same is true for many previous investigations into students' socio-scientific argumentation (e.g. Kolstø, 2006; Sadler, 2004; Sadler \& Donnelly, 2006; Sadler \& Zeidler, 2005a). The general approach has been to record student discourse and then break individual utterances into units that could be reconstructed to match the different structural elements (viz. data, claim, warrant, etc.) that Toulmin thought constituted an argument (for a critical review of the use of Toulmin's model in science education see Sampson \& Clark, 2008). This approach has practical advantages: The analyst is able to quantify large amounts of qualitative data, and can compare argumentation patterns across subjects and contexts (Andrews, 2005). But Toulmin's functional descriptions of how, for example, a warrant is different from a datum are difficult to apply on real dialogic discourse. This difficulty has been demonstrated at length in argumentation theory (Castaneda, 1960; Cooley, 1959; Cowan, 1964; Hample, 1977; Keith \& Beard, 2008; Trent, 1968; van Eemeren, Grootendorst, \& Kruiger, 1987) and in science education (Duschl, 2007; Erduran, Simon, \& Osborne, 2004; Jimenez-Aleixandre, et al., 2000; Kelly, et al., 1998). Further, structural analyses of socio-scientific discussions (such as Toulminian analyses) necessarily reduce the dialectical interactive discussion process to 
monological chains of reasoning (Habermas, 1984; Johnson, 2002; Lynch, 1982;

Smith, 1995; van Eemeren, et al., 1987). The aim of this study was to investigate the argumentative role factual scientific statements have in socio-scientific discussions. For this purpose it was important not to dismiss the dialectical dimension (i.e. how arguers use language to manage disagreement). This requirement is resonant with a recent recognition among some science educators that the dialectical features of students' argumentation deserve a closer look (Duschl, 2007; Hofstein, Kipnis, \& Kind, 2008; Kerlin, McDonald, \& Kelly, 2010; Walker \& Zeidler, 2007)

\section{Normative Pragmatics}

The concept of argumentation that formed the background of this study has been proposed by a group of scholars in argumentation theory under the name of 'normative pragmatics' (sometimes called 'design theory') (Goodwin, 2000; Jacobs, 2000; van Eemeren \& Houtlosser, 2007). From the perspective of normative pragmatics, argumentation is about managing disagreement: Argumentation is a reciprocal affair in which two or more people use language to carry out their individual project of 'influencing the decisions' of the other(s) (Goodwin, 2001, p. 14). In other words, arguers attempt to make others do something (e.g. acknowledge their standpoint, provide more reasons, clarify what they said before etc.) by designing messages that have specific effects on the recipients.

Linguistic messages have two notable aspects or dimensions: Messages have specific contents (i.e. that which is being said) but they also have specific designs (i.e. how that which is being said is said) (Jacobs, 2000). ${ }^{1}$ Taking both aspects into

\footnotetext{
${ }^{1}$ This distinction roughly corresponds to Searle's (1969) distinction between the propositional content of an utterance and the act in which that content is elicited (Jackson \& Jacobs, 1980). Argumentation from this perspective is a speech act complex. The argumentation of a speaker must have the illocutionary effect of bringing about that the interlocutor realizes that the speaker is presenting
} 
account is important for a full understanding of argumentative messages. For example, note that the following two utterances have a roughly similar content:

(1) Well you wouldn't say that merely being predisposed to be, like, really, really fat should simply be dealt with using gene therapy do you?

(2) Being predisposed to be overweight is not a condition that should fall under the purview of gene therapy treatments

The design aspects of these two utterances, however, are very different. In utterance (1), the speaker used strong evaluative adjectives and the pronoun 'you', and she elicited the content in a directive speech act (it is a question). All these aspects indicate that it would play a different argumentative role than utterance (2). In particular, utterance (1) seems to displace the balance of the burden of proof. The speech act analytical approach of normative pragmatics takes into account such design features of argumentative talk-in-interaction.

What is involved in uttering words so as to influence the decisions of others? For one, an arguer must deal with many 'practical difficulties' (such as '[securing] the adequacy of her premises') by designing her statements so as to create 'expeditiously the unchallengeable adequate premises she needs' (Goodwin, 2005, p. 100). In other words, an arguer must design and present reasons in a way that shows her interlocutor that she has adequately justified her standpoint (see also Brandom, 1994; van Eemeren \& Houtlosser, 2002). Further, in order to achieve her goal of influencing the decisions of her interlocutors, the speaker must use argumentative strategies (Goodwin, 2001). Some argumentative strategies are very simple. For example, the strategy of providing justification for a standpoint that one proposed earlier can be used to influence the recipients to hold a similar standpoint (Innocenti, 2006). Some strategies are more complex. For example, a strategy of accusing someone not only argumentation, and argumentation always involves the speaker's attempt to bring about the perlocutionary effect of convincing her interlocutor (van Eemeren \& Grootendorst, 1982). 
requests that the accused explain her position, but it also implies that her position is wrong (Kauffeld, 1998). Other strategies work by the very act of uttering something rather than on the propositional content of the act. Just as making a promise is an act that can be a reason for the recipient to act in a specific way, some argumentative strategies create 'pragmatic reasons' for the recipients to do something (e.g. acknowledge the adequacy of a premise) (Innocenti, 2006). Pragmatic reasons are created by the act of saying/doing something, while (regular, non-pragmatic) reasons are brought about by the content of a message.

Another way that a speaker can influence the decisions of others is to actively design what the disagreement is about, and thereby steer the discussion in a direction that is beneficial for her. She can, that is, design the issue that is up for discussion for an issue does not merely happen to become an object of contention, it 'arises when we make an issue of it' (Goodwin, 2002, p. 86). For example, the abortion debate can be designed as a pro-life or pro-choice issue (Craig \& Tracy, 2005).

The goal of normative pragmatics analysis is to identify 'strategies as strategies [and] explain how an arguer's utterance of some words can be expected to accomplish things like the imposition of probative burdens' (Goodwin, 2001, p. 9). Against this background, the research question behind this study (how and for what purpose do students interweave factual and evaluative statements in group discussions about a controversial socio-scientific issue?) will be approached through three analytical questions: (1) Are there different argumentative strategies that involve the weaving together of science factual and evaluative statements? (2) How do such strategies work? (3) How does the interweaving of science factual and evaluative statements contribute to the speaker's attempt to design issues?

\section{Methods}




\section{Research Design}

To elucidate the research question (through the analytical questions) three socioscientific group discussions were subjected to a normative pragmatics analysis. The study was designed as a multiple case study (Yin, 2009). Each case consisted of the transcriptions of a 45-60 minute discussion among 4-5 students about whether human gene therapy should be allowed. Three teachers in three different classes from two Danish upper secondary schools implemented the discussion activities in January and February 2010. All three teachers were experienced biology teachers and used the activity as a conclusion to their standard unit on genetics. The students in all three classes were introduced to the activity in a uniform manner, they were given the same written material, which they read in the groups immediately before the discussion, and they sat undisturbed for the majority of the activity. The similarities across the three cases afforded that findings in one case could be compared and related to findings from the other cases (Yin, 2009).

The written material - 'Gene Therapy - A Dilemma for the Future?' - was inspired by the activity 'Negotiating Gene Therapy Controversies' developed by Zeidler and Sadler (2004). It described the difference between somatic and germ-line genetic therapy, and how these technologies work. It will be helpful to recall that gene therapy on germ cells involves engineered changes that are heritable and persist throughout the lifespan of the beneficiary, whereas gene therapy on somatic (bodily) cells involves engineered changes that are not heritable and disappear with the affected cells.

The written material also presented four real life positions on whether to allow gene therapy - each supported by statements from a public debate in America. The explicit task of the students was to decide on how the European Council should be advised on future legislation regarding human gene therapy. 


\section{Sample Data}

This study was the first part of a longer study of the role of science in students' socioscientific discussions. Because of the significant amounts of data accumulated in each group discussion, this preliminary study was limited to three groups - one from each class. At the point of writing, these three groups are the only groups that have been analysed in full. The first group (group A) was chosen because it was the first group from the first class whose discussion was transcribed. The two other groups (B and C) were chosen at random from their respective classes.

\section{Analysis}

The key aim of the normative pragmatics analysis was to elucidate the analytical questions listed above. There is, however, no regimented procedure for conducting normative pragmatics analysis. Therefore a number of scaffolds were implemented so as to structure the analysis. First, the talk turns in which science was invoked were indexed. Second, the thematic issues (i.e. the issues that were discussed recurrently and at length) of the discussions were identified. This was done through two iterations of open (inductive) coding (Denzin \& Lincoln, 1994; Thomas, 2003) in which the discussions were split into sequences according to the issue that the participants discussed in that sequence. This created two basic analytical tiers that acted as guidelines for the ensuing normative pragmatics analysis.

The normative pragmatics analysis of sequences in which science factual and evaluative statements were interwoven was guided by four questions:

1) What kind of speech acts were being used (van Eemeren \& Grootendorst, 1989)? For example, questions (directives) usually have a different argumentative function than do assertions (van Eemeren \& Grootendorst, 2004).

2) What kind of argumentative indicators were explicit in the talk turn? For example, locutions such as 'yes, but...' and 'I don't think so' are indicators of 
doubt or disagreement of different strength, while locutions such as 'how do you mean?' and 'why is that so?' are indicators of requests for clarification or justification (van Eemeren, Houtlosser, \& Henkemans, 2007). This provided a basis for interpreting what the talk turn was a response to and what kind of response it was (i.e. a confrontation, justification, standpoint etc.).

3) What other linguistic indicators deserve attention? For example, pronouns (Goodwin \& Honeycutt, 2009), adjectives (Gilbert, 1997), and stance adverbs (Tseronis, 2009) can be revealing design features that can have an argumentative function.

4) What is the connection between the talk turn in question and the thematic issues of the discussion?

The normative pragmatics analysis was conducted in a hermeneutic fashion. The first two tiers of the analysis revealed places in the discussions where science and values appeared interwoven. On the basis hereof, a particular sequence of turns in the first discussion was chosen. The normative pragmatics analysis of that first sequence revealed a particular way that science and values were combined. The rest of the data were then explored for indicators of similar combinations. This led to the identification of new sequences, some of which featured a roughly similar combination, while others showed other ways that facts and values were interwoven. The latter sequences, in turn, became stepping-stones for identifications of new combinations and so on. This afforded a focus on describing the different sciencevalue combinations and how they differed. The normative pragmatics analysis was shared with and critiqued by a scholar in argumentation theory who is experienced in conducting normative pragmatics analysis.

\section{Findings and Discussion}




\section{Impressions From the First Two Analytical Tiers}

The following number of talk turns was coded as featuring science: 105 for group A (23 percent of all turns in that group); 91 for group B (18 percent); and 79 for group C (15 percent). These figures are not meaningful by themselves, but they do provide some insight into how often science is used in this sort of context. For the purpose of this study, turns which featured science were marked merely to choose where to make a detailed normative pragmatics analysis.

The second tier of the analysis identified the groups' decisions and the issues that were thematic for each group (i.e. the issues that were discussed at length and recurrently). All final decision of the three groups displayed openness to both germline and somatic gene therapy, with the reservation that germ-line gene therapy is a last resort only to be used on very few diseases and with utmost caution. For some students, this meant that considerable compromises needed to be made. For example, Allan (group A), Dwight (group B), and Anita (group C) all consistently held that germ-line gene therapy should not be allowed; but their respective peers eventually persuaded them otherwise.

Three thematic issues were occurred in every group. First, every group discussed the concern that misuse of gene therapy could have unfortunate social consequences. For example, using the technology to change 'appearances' (Betsy, B188), decide whether a 'child should be homosexual or not' (Bettina, A306), entirely 'eradicate [a] disease' (Diana, C364), or even to create extreme socio-economic gaps so that 'those who have money that can get the healthy, smartest and most beautiful children' (Dwight, B186). Second, every group discussed which diseases would be legitimate objects for gene therapy treatment. For example, cancer was often brought to the table: 'of course one could not say that cancer, that one should not do that...if it could be changed using germ-line gene therapy' (Allan, A171). But the issue also 
concerned how to draw the line between legitimate and illegitimate diseases: 'one should have a clear definition of when a disease is a real disease if one could put it that way' (Christina, C52). Third, every group discussed the long-term effects of germ-line gene therapy and in all discussions this was identified and acknowledged as an (at least potential) ethical problem. For example, Allan argued that germ-line gene therapy 'has that lasting effect $\lceil\ldots][$ so] I think also still that it's dangerous to say that this should just be researched' (A142). Allan thus proposed not to allow germ-line gene therapy research based on a concern about the long-term effects of germ-line therapy (coupled with the concern that research in such a field would have an impact). One of the key potential ethical issues concerning the long-term effect that the students identified was the concern that it might violate a persons right to an "open future" (Feinberg, 1980) - the concern, that is, that the autonomous choices of, for example, parents or societal institutions might severely limit the autonomy of the beneficiary (Davis, 2006; Takala, 2005). For example, Christina argued that by using germ-line gene therapy 'we, well, go in and then choose on behalf of another individual in some way' (C52). Thus, in every group, one of the primary arguments raised against germ-line gene therapy was the concern that persons who are not the result of genetic engineering have an autonomy which is qualitatively more desirable or greater than that of persons who are the result of genetic engineering. In sum, the bioethical issues that are usually identified as the core potential issues or dilemmas concerning gene therapy - namely, the fear that gene therapy is a slippery slope, the fear that gene therapy leads to eugenics, and the fear that germ-line gene therapy closes the future of its beneficiaries (Holland, 2003; Wilkinson, 2010)-were reproduced and discussed as key issues in every group. This does not mean that every participant shared these core concerns. In fact, all groups eventually decided on taking 


\section{a rather positive stance towards gene therapy. But it does emphasise that even if one}

believes that gene therapy is sound - from an ethical perspective - the core issues

outlined above still need to be discussed as potential issues of concern (see in

particular Harris, 1993).

\section{Normative Pragmatics Analysis}

Science and value-statements in socio-scientific discussions

Even though a socio-scientific decision necessarily involves at least one value judgement, scientific statements seem particularly apt to be starting points (i.e. the 'bare' facts that a discussion can be had in light of) in such discussions. The clearest structure of a socio-scientific argument could be portrayed as follows: In light of these and these facts about $\mathrm{Y}$, and because $\mathrm{Z}$ is valued, $\mathrm{X}$ should be done. This structure was regularly found, and it can be illustrated with these examples:

A203 Allan: Yes yes, but that is what I mean, that one maybe therefore should be more passive regarding that germ-line gene therapy because it has a lasting effect

B97-9 Dwight: as soon as you make germ-line treatment $[\ldots]$ well then the offspring that two persons get is not genetically identical with them. That, I think, is a big crisis [...] that I think is ethically completely irresponsible that the offspring one gets is not genetically identical with oneself

In such cases science content is kept separate from evaluative statements. When a speaker presented this structure of argumentation, her peers were invited to engage in a pro- and contra-argumentation about the values (e.g. 'do we value other values higher than Z?'), and to engage in a negotiation of the practical conclusion of the argumentation (e.g. 'should we really do X?').

The fusion of value-statements and science content

Emily in group $\mathrm{C}$ argued for allowing 'some forms of gene therapy, that is, on these life-threatening diseases' (C26)

C28 Emily: [...] because I don't feel that you can totally ignore that you 
can actually cure an enormous number of unbelievably horrible diseases by using this and then just chose to say we don't want that

Here Emily used a scientific fact about gene therapy (that gene therapy can cure diseases) as part of her reason for why gene therapy should be allowed. Three design aspects of her argumentation stand out. First, the stance adverb 'actually' (in Danish: 'faktisk') indicates that Emily insists that gene therapy indisputably can cure diseases; and that she anticipates that this indisputable fact is incompatible with the argumentation of her opponents (Tseronis, 2009, pp. 70-1). In fact, although group C later discussed how both kinds of gene therapy function as a cure and what kinds of diseases should legitimately be treated using gene therapy, the group never discusses which diseases gene therapy can cure or treat. So in the context of this group, the statement 'gene therapy can cure diseases' has already evolved into what Latour and Woolgar (1979) called a 'type 5 statement,' a 'taken-for-granted fact' that is made explicit only in rare situations (e.g. involving people how require 'some introduction' to it) (Latour \& Woolgar, 1979, p. 76).

Second, Emily used the evaluative adjective 'enormous,' and the emotive adjectives 'unbelievably horrible.' This indicates that Emily was doing more than introducing a 'taken-for-granted fact.' To say that the diseases that gene therapy can cure are both plentiful and 'unbelievably horrible' is to make an evaluation; it is not a scientific fact. (This is so because an assertion to the effect of "disease $\mathrm{X}$ is unbelievably horrible" is not an assertion that could be either definitely true or definitely false; science could possible test whether persons in general think that disease $\mathrm{X}$ is unbelievably horrible, but whether it is correct to think that a disease is unbelievably horrible is not a determinate question). Emily made an appeal to emotions by installing emotive adjectives (Gilbert, 1997; Innocenti, 2006); but, more importantly, she chose to fuse the emotive adjectives with the science factual 
statement in one assertion. The science-evaluation package that Emily presented can be seen as an attempt to make the value-laden statement '[gene therapy] can actually cure an enormous number of unbelievably horrible diseases' into an indisputable starting point for the discussion (i.e. something that the arguers mutually agree on). In other words, Emily made it appear that her value-judgement is indisputable by piggybacking it on the indisputability of a scientific factual statement.

Third, Emily designed her turn as a challenge to possible opponents.

According to Emily, those who do not think that gene therapy should be allowed would say 'we don't want' to allow gene therapy and they would 'totally ignore' the benefits of gene therapy. Not only is this a possible line of counter-argumentation against the standpoint of those who are opposed to gene therapy, it can be seen as a way of requesting a particular line of argumentation from those who are opposed. Emily's strategy was to 'make an issue of' whether or not to ignore the benefits of gene therapy, and she made it apparent that her potential opponents are 'obligated, or forced by circumstances, to address' why they ignore the benefits, and, if they do, why they are justified in doing so (Goodwin, 2002, p. 88). Emily's opponents would have to have considered themselves challenged to show that they are not 'totally' ignoring what she takes to be ever so obvious benefits of gene therapy. In other words, Emily's potential opponents must not only give positive reasons for being opposed; they must argue why they are opposed even in light of the benefits of gene therapy (viz. that it can 'cure an enormous number of horrible diseases'). It is precisely because the benefits of gene therapy are introduced as indisputable that Emily's potential opponents would be required to present that line of argumentation In sum, Emily (i) fused evaluative terms like 'unbelievably horrible' to a scientific factual statement and (ii) presented a value-science package as indisputable. 
Further, (iii) the very act of presenting the value-science package created a pragmatic challenge to Emily's interlocutors - putting them in a position where they would have to undertake an unacceptable burden of proof if they would deny the value-science package claim. In the end, this strategy of fusing-presentation-challenge actually worked to make the value-science package a starting point for the rest of the discussion.

Values and science were interwoven in other ways. Bettina (group A)

\section{presented a factual scientific statement alongside a value-laden description of some} possible macro-social circumstances as being undesirable. She did so in a way that made it appear that there is an indisputable causal link between allowing germ-line gene therapy and unacceptable macro-social circumstances:

A12 Bettina: In the book it also says [...] that if one found out that there were some gene-errors in a foetus and one went there to change it then the diseases that the foetus might have gotten, then they would become much more tabooed; and then those that were born with the disease they would feel that they shouldn't have been alive

By appealing to the authority of 'the book', Bettina used the science fact that the predisposition to hereditary diseases can be removed by using germ-line gene therapy. Bettina, unlike Emily, did not present an evaluative judgement per se together with that science fact. But Bettina did point to some undesirable macro-social outcomes of allowing germ-line gene therapy - namely, that such treatable hereditary diseases 'would become much more tabooed,' and in particular, that the persons who for some reason were not treated would be burdened with guilt. These assertions are not in themselves value-statements, but the implicit undesirability of the outcome (which would be a value-laden claim) leads to a blurring of the fact-value distinction. The interweaving of facts and values in the case of Bettina, unlike in the case of Emily, accomplished to naturalise a link between using germ-line gene therapy and some macro-social consequences that are unacceptable according to a set of values that 
remained implicit in the argumentation of Bettina's. As such this is a slippery slope argument, which is fallacious unless one explicitly points to the causal mechanisms that make the slope slippery (Govier, 2010). But rather than saying which causal mechanisms would work this way, Bettina made it appear that the causal link is indisputable; and she used that indisputability to challenge her opponents by making it apparent that if one allowed germ-line gene therapy, one would either be logically inconsistent or have an unacceptable burden of proof as to why such macro-social consequences could be tolerated. It is unclear whether it was Bettina's talk turn that successfully established the indisputability of that causal link in discussion A, but it is a recurrent theme in the discussion of the group, and she did actually consistently use the apparent indisputability of the causal link in the discussion: e.g.

A306 Bettina: [...] if it is the case that one can go in and change whether one's child should be homosexual or not; then it becomes a giant taboo for the others

In cases such as Emily and Bettina's evaluative judgments are explicitly interwoven with science factual claims. The focus of the next sections will be on more complex instances of how facts and values were combined.

\section{The conjunction of scientific statements and confrontation}

Talk turns in which the speaker exposes, defines or explains a science concept (e.g. phrases such as 'germ-line gene therapy is about changing the genes of the zygotes') enjoy a special status. Such talk turns are not in themselves arguments (Govier, 2010). They typically consist of speech acts such as declarations (e.g. 'No, I was talking about germ-line cells', 'force is that which causes a body to accelerate') and often only contribute to argumentation by enhancing 'the understanding of other relevant speech acts' (van Eemeren \& Grootendorst, 2004, p. 66). But in some cases explanations of science concepts had argumentative purposes in talk sequence in which they were located. The students in this study at times injected evaluative terms 
into their explanations of science concepts. Gilbert (1997) has argued that expressive message declarations - such as 'it's as if one makes a decision on behalf of one's future children' (Connie, A195) - 'can lead and turn the argumentation in ways that might not have been anticipated' (Gilbert, 1997, p. 5). In other words, such expressive declarations are devices that speakers can use to design issues.

Betsy from group B undertook to explain to Andrea exactly what germ-line gene therapy is:

B149 Betsy: It is the germ-line cell of a mother and a father. Then you go in and mate them and then you say okay there is a disease here that might kill them when they are 17 so that if there is one can maybe remove that disease and they can live without dying when they are 17

Abstracted from its context, the turn seems to be merely an explanation - not an argument. Also, it is not obvious that Betsy fused the science content with evaluative terms. Betsy, rather, gave a (relatively fitting) factual account of how germ-line gene therapy works and what it can be used for - namely that the technology 'can maybe remove' diseases that otherwise would 'kill' patients 'when they are 17'. But notice how Betsy chose to exemplify the workings of germ-line gene therapy. The example that Betsy chose (i.e. removing diseases that kill you when you are 17) was not arbitrary; she used it recurrently: e.g.

B91 Betsy: it would still be great if one could remove those diseases like for example cystic fibrosis so that there aren't people who go around and die from it when they are 17

Judging from the context of Betsy's turn 149, it becomes clear that Betsy was, in fact, arguing. For in the following turn she pointed to Dwight and said:

B151 Betsy: And that's what he ((points to Dwight)) thinks that one is not allowed to do

It now becomes clear that when Betsy presented her explanation she laid the groundwork for a challenge to Dwight - who at that time was strictly opposed to allowing germ-line gene therapy. According to Betsy, then, Dwight would not take the necessary steps to alleviate patients with diseases that 'kill them when they are 17' 
and thus stop such patients from 'dying when they are 17' (Betsy, B149). The strategy that Betsy used was to turn the issue about whether or not to allow germ-line gene therapy into an issue about whether or not to rescue some patients from a certain and untimely death.

The strategy of presenting a scientific explanation in conjunction with a valueladen confrontation functions in a similar manner to the strategy that Emily used above: It potentially challenges the opponent with an unacceptable burden of proof if she or he denies the standpoint. One of the reasons that the strategy can be successful might be the factual character of the scientific explanation. For whether or not germline gene therapy can be used to remove the genes that makes a person disposed to having these diseases is what Goodwin would call a 'highly determinate' issue in the sense that there is no 'middle ground' - either germ-line gene therapy can do this or it can't (Goodwin, 2002, p. 83). This is not so for the 'germ-line gene therapy'-issue that the group was discussing (i.e. whether or not to allow germ-line gene therapy). The latter issue is significantly less determinate than the former. But Betsy used an explanation of how germ-line gene therapy works as a device that turned the less determinate 'germ-line gene therapy'-issue into an issue about whether or not to help patients. And the latter issue can be presented as if it was highly determinate - in the sense that either you are opposed to rescuing these patients or you are not. The upshot, then, is that Betsy's presentation can be interpreted as a strategy that designs the issue so that it becomes considerably more difficult for Dwight (and others who have a similar standpoint) to argue that germ-line gene therapy should not be allowed.

\section{Complex confrontation}

The strategy of presenting a scientific explanation in conjunction with a value -laden confrontation can also work in cases where the target of the confrontation is disguised 
or where the confrontation is implicit. In turn C131, Anita disagreed with Diana's claim in turn $\mathrm{C} 130$ that no one objects to 'do research in' germ-line gene therapy:

C130 Diana: I don't think that there are any who say that one shouldn't do research in [germ-line gene therapy]

C131 Anita: yes, but I believe there are. I believe that

C132 Christina: There are those...

C133 Anita: everything with germ-line cells, there you go in and steal lives in some way if there is anything that goes wrong

In turn C133 Anita used the scientific information that germ-line genetic therapy has consequences for every cell in the resulting person seemingly to provide a reason for her disagreement (i.e. that there are people who object to research in germ-line gene therapy). As will be argued, there are indications in other parts of the discussion that Anita in turn C133 is confronting more than just Diana's standpoint in C130.

How does turn C133 work with respect to turn C130? According to Anita's exposition, it is the nature of germ-line gene therapy that if things go wrong at the level of pre-embryonic engineering there is the risk that the potential embryo will not develop properly (hence the medical engineers would 'steal' the life of that beneficiary). The expression 'steal lives' indicates a specific appeal to emotion but, as it stands, it is unclear that Anita fused science and values explicitly (like Emily did). Notice, 'steal lives' is not necessarily a result of an evaluative judgement about whether or not embryos are persons. Anita could just have referred to a fact she made earlier: that 'if one changes the genes' in the pre-embryonic state it could result in a situation where that beneficiary 'gets an entirely different behaviour' (Anita, C30). Regardless of whether or not Anita (in turn C133) fused science and values into one assertion, her act of presenting that particular exposition of what germ-line gene therapy is could create a pragmatic reason for accepting that there are some who would find germ-line gene therapy research morally objectionable.

Anita's main interlocutors were Diana and Emily, who both to some extent 
endorsed germ-line gene therapy - or at least that it would be 'stupid to close one's eyes to [its benefits]' (Emily, C71). Anita was consistently opposed to germ-line gene therapy (at least until the very end of the discussion), and her way of reacting to the others' talk about germ-line gene therapy throughout the discussion displayed a particular pattern of presenting the type of exposition found in C133: e.g.

C30 Anita: $\begin{aligned} & \text { one knows the consequences of that germ-line cells, one knows } \\ & \text { what consequences it has if one changes the genes because, as } \\ & \text { we talked about yesterday, if one then gets an entirely different } \\ & \text { behaviour and grows up to be someone entirely different than } \\ & \text { who one maybe should be }\end{aligned}$

C179 Anita: But the thing, like, is, you see, that one can, after all treat now with these somatic cells, but it's just not permanent, see...

In light of this it is not clear that C133 was designed only as a reason for why Anita thinks Diana was wrong in turn C130. It seems more likely that Anita took Diana's standpoint that no one objects to research in germ-line gene therapy as a part of Diana's argumentation for allowing germ-line gene therapy treatments. The pattern that Anita displayed suggests that her expositions of what germ-line gene therapy is were part of a co-optive strategy: she redesigned the issue about whether or not to allow germ-line gene therapy into an issue about whether or not to permanently alter the potential beneficiary or even expose the embryo to grave dangers in the process. This strategy makes sense as a reaction to, for example, Emily's attempt to frame the issue about gene therapy as whether or not to cure 'unbelievably horrible diseases.' But the issue that Anita introduced is, as in Betsy's use of confrontation above, seemingly more determinate than the issue about whether or not to allow germ-line gene therapy. For example, it could be conjectured that many people would find it more difficult to approve of 'steal[ing] lives' than to approve of research in germ-line gene therapy.

The upshot of the case of Anita versus Diana (and Emily) is that it is not 
always obvious what the target of a strategically presented explanation of a science concept is; and that analysts in some cases need to take the dialectics of the entire discussion into account in order to interpret what kind of issue the speaker is designing at a particular point.

\section{The use of science to push an ethical stance}

The focus has so far been on how specific ways of presenting science factual claims can influence the apparent acceptability of evaluative judgements about particular issues (e.g. the potential of germ-line gene therapy) or even causal processes (e.g. the causal effects of allowing gene therapy). But in some situations science is also used as a device that pushes or reinforces a specific conception of the Good. Dwight and Betsy argued about whether or not to allow somatic gene therapy. Dwight was for using that technology; Betsy was against:

B255 Dwight: Why do you not want somatic?

B256 Betsy: There I just have something... when they have become people ... when they have become ... come out and they are as they are supposed to be, that you should damned not fiddle more with them. No, that, I can't... That, I can't have

B279 Betsy: $[\ldots]$ when they have become humans then there is a reason [Danish: 'mening' is equivocal: could also be 'meaning' or 'purpose'] for it, damn it

B309 Betsy: [...] it [somatic gene therapy] is to go in and change when they have become humans

B312 Dwight: But Betsy, you forget that our cells are constantly being changed, because we surround us with radioactive sources all the time. I have a cell phone here ((gestures to his pants pocket))

B318 Dwight: [...] cancer comes from mutations in the cells, that do that there is a change in genes. Why are we then not allowed to do the same? When people actually agree that cancer mutations are not natural, but for example can happen because you smoke then your chance for mutations increase. Why can't we do it the other way around? And try to treat it in the same way as it comes

According to Betsy, somatic gene therapy should not be allowed because that would be to 'fiddle' with 'people' in a way that is not permissible because they are humans 
that have 'become' who they are for a reason and should not be 'changed'. Dwight's strategy was to challenge Betsy's argumentation by presenting just how normal it is that cells change as a consequence of interaction with the environment.

Dwight elicited science content in the two turns B312 and B318 (viz. 'our cells are constantly being changed', 'cancer comes from mutations in the cells that do that there is a change in genes', 'cancer mutations [...] can happen because you smoke'). He used three particular design choices to challenge Betsy. First, Dwight established that human cells change over time as an indisputable fact, not by simply stating it but by saying that Betsy is forgetting that fact. Short of directly accusing one's opponents of being logically inconsistent, to say that they 'forget' something in their reason is a form of face-saving device. Pragmatically it creates a challenge to the Betsy's standpoint by making it appear that it is just a matter of Betsy realizing the forgotten fact for her to come to Dwight's conclusion (that somatic gene therapy should be allowed). Second, Dwight (in turn B318) says that "people actually agree that cancer mutations [...] can happen because you smoke'. As with the case of Emily, the stance adverb 'actually' indicated that Dwight insists on the indisputability of the ensuing claim (Tseronis, 2009). Third, Dwight's usage of the pronoun 'people' is revealing: The people he referred to are hardly laypersons. In that sense he insisted on experts agreeing 'that cancer mutations [...] can happen because' of human conduct. As such Dwight appealed to expert authority (cf. Goodwin \& Honeycutt, 2009). In sum, turns B312 and B318 can be recognized as acts that did more than simply convey scientific information about human cells - they also installed doubt in Betsy's argumentation on account of Betsy missing something obvious and indisputable.

Turn B318 is complicated by the fact that Dwight did two things at once. On 
It is not arbitrary that Dwight turned the issue about whether to allow somatic gene therapy into the issue about whether somatic gene therapy is natural. There are indications in other parts of the discussion that there is more at stake for Dwight than just persuading Betsy and the others that somatic gene therapy should be allowed on certain diseases. At multiple times in the discussion he elicits an ethical worldview according to which the Good corresponds to what is natural and the bad corresponds to what is unnatural:

B49-50 Dwight: $\quad[\ldots]$ we are purely a product of nature so the thoughts we have now, they are a product of nature. That means that we can principally, seen from nature, not be wrong

B55 Dwight: [...] To my mind it can't be wrong to really wish to come further scientifically and to say that it is against nature when we are just a product of nature 
B399 Dwight: [Somatic gene therapy] is not unnatural to the same degree [than germ-line gene therapy is]

Dwight's challenge to Betsy's argumentation in turns B312 and B318 can be interpreted as a way of reinforcing that ethical worldview. On this interpretation Dwight used the scientific fact of cell mutation being a constant part of life not just as way of supporting his stance that somatic gene therapy should be allowed (on some diseases), but as a vehicle in a continuous attempt to enforce a sort of ethical naturalism.

\section{Similarities and Differences in the Presented Usages of Science}

This study has shown that when students use science to argue for an evaluative claim it is often not just a matter of conveying information. For the speaker, it is often a matter of demonstrating that her evaluative claim is more solidly supported than the one of her addressees or that the evaluative claim of her addressees is insufficiently supported.

There are some differences between the explored cases. But, as will be argued below, all cases are different manifestations of a general strategy in which the speaker blurs the fact-value distinction for argumentative purposes by presenting science content in conjunction with a value-laden challenge to the interlocutor. The differences between the cases - as suggested by the sub-headings of the preceding section - is primarily in terms of the complexity with which the strategy of blurring the fact-value was carried out (ranging from 'simple' cases where values were fused with factual scientific statements in one assertion to dialectically complex cases where the execution of the strategy happened over a considerable number of talk turns). The differences in terms of complexity indicate that it is not enough merely to observe whether a given utterance has factual and evaluative content because science and 
values can be interwoven in various ways and to various degrees. Even though a

given science factual claim bears no evaluative content it could very well be used in a

way that supports adjacent (or implicit) evaluative claims. There is, further, a

difference between the cases in the sense of the outcomes of the execution of the

strategy of blurring the fact-value distinction. In particular, science can be co-opted

(a) to make an evaluation of the technology appear indisputable (e.g. gene therapy can

$\underline{\text { cure 'unbelievably horrible diseases'); (b) to introduce a particular causal link }}$

between using the technology and some undesirable consequences as if that link was

indisputable (e.g. the diseases that are not treated with gene therapy 'would become

much more tabooed'); or (c) to reinforce a particular view of what is natural or a

particular conception of what is 'good' (e.g. 'we can principally, seen from nature, not

be wrong'). Such differences, both in terms of complexity and pursued outcome, must

be kept in mind when researchers or teachers assess students' socio-scientific

discourse.

For each of the presented cases it has been shown how the notion of designing issues aids the understanding of the strategies in which science and values are interwoven in a way that blurs the fact-value distinction. Science can be co-opted so as to steer the discussion in a specific direction. This finding is an elaboration of, or comment to, the findings of Lewis and Leach (2006) that the conceptual science knowledge of students determines which aspects they find in a socio-scientific issue and that this in turn determines the attitudes they express (for a similar interpretation see Fowler, Zeidler, \& Sadler, 2009). Clearly, it must be correct that science knowledge, for example the knowledge that there are two types of gene therapy and that they differ substantially, is required for a person to identify the difference between the two types of gene therapy as an issue that is worth arguing. But, as has 
been argued in this paper, issues do not just happen to become objects of contention; they are made such objects. And the students in this study did not seem to make such issues in lack of other issues to find. Rather, they used science to design issues so as to feather their own argumentative nests.

Each of the explored cases represents a unique way of designing issues.

Nevertheless, all cases display a general pattern or strategy: the speaker presented science content in conjunction with creating a value-laden challenge to the interlocutor. Three affordances of the pattern deserve emphasis. First, a speaker can use the stragtegy to blur the fact-value distinction so as to make it appear that her value-laden challenge (or any evaluative claim) is authorized by science. In other words, something that should be up for discussion is guised as something beyond every doubt.

Second, the strategy can make it appear that a particular issue is - factually speaking - more important than other issues. If the speakers' challenge to her opponent appears to be authorized by science she can use that authority to make it apparent that her take on what the issue 'really' is, is more firmly grounded in 'the facts' than the issue entertained by her opponent.

Third, the strategy can make it appear that there is a clear answer to the issue at hand. Most science issues, at least at the level of secondary school science, are highly determinate (Goodwin, 2002). In contrast to this there is no clear right or wrong answer to the issue about whether or not to allow gene therapy. However, if a speaker can successfully make it appear that science authorizes that the gene therapy issue is actually an issue about making sure that a group of 17 year olds do not face an untimely death, she would have turned an irresolvable issue into an easy choice. So it is not just that science can make it seem that a particular issue is the "real" issue, the 
scientification of that issue makes it appear that there is a clear answer to how people should deal with it.

\section{Limitations}

The small-scale nature of this investigation afforded an interpretation of the data in great detail - a potential that was also harnessed by Pouliot (2008) in a study of students' conceptions of socio-scientific issues. Both in terms of scale and purpose this study was exploratory and in that sense it followed the lead of a number of recent qualitative explorative studies on discursive aspects of socio-scientific issues by explicitly not attempting to be generalisable or exhaustive (Albe, 2008; Barrett \& Nieswandt, 2010; Lindahl, 2009; Marttunen, 1997; Pouliot, 2008; Sadler, 2006; Sadler \& Zeidler, 2005a). The aim was not to count or enumerate the instances in which science factual and evaluative statements were interwoven. There are undoubtedly other ways in which the blurring of the fact-value distinction can be used strategically and such strategies also deserve to be analysed and explained. The type and frequency of a particular kind of strategy will probably vary corresponding to physical context, the question that is being discussed, and the people involved. Further, this study cannot address whether student's level of scientific knowledge had an impact on whether they co-opted science. Goodwin and Honeycutt (2009) found that also scientists also perform appellative argumentative moves when discussing socio-scientific issues with laypersons. So the speaker's level of knowledge seems to underdetermine which way she uses science in discussions. To establish such an impact of different degrees of scientific knowledge future investigated are needed. Finally, it is hard to know the extent to which the results can be generalized without a random sample. This study, however, is not meant to comment on the frequency with which these strategies are used in the general population. Rather, the modest aims of 
this study were to demonstrate that such strategies exist, describe how they work, and show how they can be used.

\section{Conclusion and Implication}

The most important issue raised by this study is the difficulty of addressing the factvalue distinction in science teaching. There are dimensions of students' socioscientific argumentation that need to be researched in more detail. It is of course important to focus on students' reasoning abilities in terms of evidence-giving procedures (as documented by Sadler \& Zeidler, 2005b), but the findings of this study suggest that following evidence-giving procedures is just one aspect of successful socio-scientific arguing. In dialectical socio-scientific discussions, arguers not only use science to justify their standpoints, they also use science to authorize that certain issues are more central for making a decision than others. If such aspects become the topic of future research, researchers need to apply analytical frameworks that take into account the dialectical aspects of students' argumentation.

Research on students' argumentation in science education has primarily been concerned with the content of science factual utterances. The focus has been on what a student said and which kind of argumentative function (claim, warrant, data, etc.) that propositional content can be interpreted as having. This study has shown that a number of aspects (such as strategies in which science is used in a co-optive fashion) in students' argumentative discourse on socio-scientific issues can only be fully understood through a focus on how the scientific content in utterances plays together with the design of such utterances (i.e. how the content is elicited in the utterance). A conspicuous design choice (e.g. asking a question) is neither arbitrary nor impotent. A focus only on the content (or structure) of argumentation neglects that, in practice, arguers perform speech acts that are designed to show (rather than tell) that a 
standpoint has been adequately argued for.

Using science to make it appear that one's value judgements are to be exempt from criticism is at odds with an arguer's dialectical obligations, if not outright fallacious. In practical contexts of deliberation, it must be case that the reasons that an arguer presents are subject to scrutiny (Kock, 2008). Even though the different cooptive usages of science all had something to do with the naturalistic fallacy (of taking a leap from the descriptive to the normative) they work and look differently, and they are not always immediately obvious.

Scholars who are interested in socio-scientific decision-making as learning activities should take the findings of this study as an emphasis on the complexity of such activities. Even if teachers encourage students to use science argumentatively so as to make evaluative decisions, there are multifarious ways in which science can be used. The findings, in particular, suggest that teachers and science education researchers need to be aware of the complexity with which science and values can be interwoven in such activities. From the perspective of teachers this means that much more work needs to be done in order to sort out how the fact-value distinction should be addressed appropriately. From the perspective of researchers it means a continued negotiation of what they mean when they say that students' should become able to use science on issues from outside science.

\section{References}

Albe, V. (2008). Students' positions and considerations of scientific evidence about a controversial socioscientific issue. Science \& Education, 17(8-9), 805-27.

Andrews, R. (2005). Models of argumentation in educational discourse. Text: Transactions of the Society for Textual Scholarship, 25(1), 107-27. Armstrong, D.M. (1997). A World of States of Affairs: Cambridge University Press. Aufschnaiter, C.v., Erduran, S., Osborne, J., \& Simon, S. (2008). Arguing to learn and learning to argue: Case studies of how students' argumentation relates to their scientific knowledge. Journal of Research in Science Teaching, 45(1), 101-31. 
Barrett, S.E., \& Nieswandt, M. (2010). Teaching about ethics through socioscientific issues in physics and chemistry: Teacher candidates' beliefs. Journal of Research in Science Teaching, 47(4), 380-401.

Brandom, R.B. (1994). Making It Explicit: Reasoning, Representing, and Discursive Commitment: Harvard University Press.

Castaneda, H. (1960). On a proposed revolution in logic. Philosophy of Science, 27992.

Clark, D.B., \& Sampson, V. (2007). Personally-Seeded Discussions to Scaffold Online Argumentation. International Journal of Science Education, 29(3), 253-77.

Cooley, J. (1959). On Mr. Toulmin's revolution in logic. The Journal of Philosophy, 56(7), 297-319.

Cowan, J. (1964). The Uses of Argument - An apology for logic. Mind: A Quarterly Review of Philosophy, 73(289), 27.

Craig, R., \& Tracy, K. (2005). "The issue" in argumentation practice and theory. In F.H. van Eemeren \& P. Houtlosser (Eds.), Argumentation in Practice (pp. 1128). Amsterdam: John Benjamins.

Davies, D.S. (2006). Genetic Dilemmas and the Child's Right to an Open Future. In Helga Kuhse \& Peter Singer (Eds,), Bioethics: An Anthology (pp. 246-256). Oxford: Blackwell Publishing Ltd.

Dawson, C. (2000). Selling snake oil: must science educatorscontinue to promise what they can't deliver. . In RT Cross \& P Fensham (Eds.), In Science andthe citizen for educators and the public. Melbourne: Arena Publications.

Denzin, N.K., \& Lincoln, Y. (1994). Handbook of qualitative research. Thousand Oaks, CA: Sage.

Dewey, J. (1981). The Later Works, 1925-1953. Carbondale: Southern Illinois University Press.

Driver, R., Newton, P., \& Osborne, J. (2000). Establishing the norms of scientific argumentation in classrooms. Science Education, 84(3), 287-312.

Duschl, R.A. (2007). Quality Argumentation and Epistemic Criteria. In Sibel Erduran \& María Pilar Jiménez-Aleixandre (Eds.), Argumentation in Science Education (pp. 159-75). Dordrecht: Springer Netherlands.

Erduran, S., Simon, S., \& Osborne, J. (2004). TAPping into argumentation: Developments in the application of Toulmin's Argument Pattern for studying science discourse. Science Education, 88(6), 915-33.

EU-Commision. (2004). Europe needs more scientists. Report by the High Level Group on Increasing Human Resources for Science and Technology in Europe, 1-215.

Feinberg, J. (1980). The Child's Right to an Open Future. In William Aiken \& Hugh LaFollette (Eds.). Whose Child? Children's Rights, Parental Authority and State Power (pp. 124-53). Totowa (NJ): Littlefield, Adams \& Co.

Fowler, S.R., Zeidler, D.L., \& Sadler, T.D. (2009). Moral sensitivity in the context of socioscientific issues in high school science students. International Journal of Science Education, 31(2), 279-96.

Galvão, C., Reis, P., Freire, S., \& Almeida, P. (2010). Enhancing the Popularity and the Relevance of Science Teaching in Portuguese Science Classes. Research in Science Education, 1-16.

Gilbert, M.A. (1997). Prolegomenon to a Pragmatics of Emotion. Paper presented at the Ontario Society for the Study of Argumentation, Brock University, St. Catherine's, ON. Retrieved from 
http://www.yorku.ca/gilbert/argthry/argthry/arg-papers/mag1997-prolemo.pdf.

Goodwin, J. (2000). Comments on 'Rhetoric and Dialectic from the Standpoint of Normative Pragmatics'. Argumentation, 14(3), 287-92.

Goodwin, J. (2001). One Question, Two Answers. In H.V. Hansen, C.W. Tindale, J.A. Blair, R.H. Johnson \& R.C. Pinto (Eds.), Argumentation and Its Implications (pp. 1-17). Windsor, Ontario: Ontario Society for the Study of Argument, CD-ROM, ISBN:0-9683461-2-X, Retrieved from http://www.public.iastate.edu/ goodwin/pubs/goodwinone.pdf.

Goodwin, J. (2002). Designing issues. In F.H. van Eemeren \& P. Houtlosser (Eds.), Dialectic and rhetoric: The warp and woof of argumentation analysis (pp. 8196). Amsterdam: Kluwer.

Goodwin, J., \& Honeycutt, L. (2009). When Science goes Public: From Technical Arguments to Appeals to Authority. Studies in Communication Sciences, 9(2), 19-30.

Govier, T. (2010). A Practical Study of Argument. Belmont: Wadsworth Cengage Learning.

Habermas, J. (1984). The Theory of Communicative Action: Reason and the rationalization of society (T. McCarthy, Trans.). Boston: Beacon Press.

Hample, D. (1977). The Toulmin model and the syllogism. Journal of the American Forensic Association, 14, 1-9.

Hare, R.M. (1952). The Language of Morals. Oxford: Clarendon Press.

Harris, J. (1993). Is Gene Therapy a Form of Eugenics? Bioethics, 7(2-3), 178-87.

Hofstein, A., Kipnis, M., \& Kind, P. (2008). Learning in and from Science Laboratories: Enhancing Students' Meta-Cognition and Argumentation Skills. In C.L. Petroselli (Ed.), Science Education Issues and Developments (pp. 5994). New York: Nova Science Publishers.

Holland, S. (2003). Bioethics. A philosophical Introduction. Cambridge: Polity.

Innocenti, B. (2006). A normative pragmatic perspective on appealing to emotions in argumentation. Argumentation, 20(3), 327-43.

Irwin, A., \& Wynne, G. (1996). Misunderstanding science. Cambridge: Cambridge University Press.

Jackson, S., \& Jacobs, S. (1980). Structure of conversational argument: Pragmatic bases for the enthymeme. Quarterly Journal of Speech, 66(3), 251-65.

Jacobs, S. (2000). Rhetoric and dialectic from the standpoint of normative pragmatics. Argumentation, 14(3), 261-86.

Jimenez-Aleixandre, M., Rodriguez, A., \& Duschl, R. (2000). Doing the lesson or doing science: Argument in high school genetics. Science Education, 84(6), 757-92.

Johnson, R.H. (2002). Manifest rationality reconsidered: Reply to my fellow symposiasts. Argumentation, 16(3), 311-31.

Kauffeld, F.J. (1998). Presumptions and the distribution of argumentative burdens in acts of proposing and accusing. Argumentation, 12(2), 245-66.

Keith, W., \& Beard, D. (2008). Toulmin's Rhetorical Logic: What's the Warrant for Warrants? Philosophy and Rhetoric, 41(1), 22-50.

Kelly, G., Druker, S., \& Chen, C. (1998). Students' reasoning about electricity: Combining performance assessments with argumentation analysis. International Journal of Science Education, 20(7), 849-71. 
Kerlin, S., McDonald, S., \& Kelly, G. (2010). Complexity of Secondary Scientific Data Sources and Students. International Journal of Science Education, 32, 1207-25.

Kitcher, P. (2010). The Climate Change Debates. Science, 328(5983), 1230-4.

Kock, C. (2008). Dialectical Obligations in Political Debate. Informal Logic, 27(3), 223.

Kock, C. (2009). Choice is Not True or False: The Domain of Rhetorical Argumentation. Argumentation, 23(1), 61-80.

Kolstø, S.D. (2000). Consensus projects: teaching science for citizenship. International Journal of Science Education, 22(6), 645-64

Kolst $\varnothing$, S.D. (2001). 'To trust or not to trust, . . .'- pupils' ways of judging information encountered in a socio-scientific issue. International Journal of Science Education, 23(9), 877-901.

Kolstø, S.D. (2006). Patterns in Students' Argumentation Confronted with a Risk $\square$ focused Socio $\square$ scientific Issue. International Journal of Science Education, 28(14), 1689-716.

Latour, B., \& Woolgar, S. (1979). Laboratory life: the social construction of scientific facts. Beverly Hills: Sage Publications.

Levinson, R. (2007). Towards a pedagogical framework for the teaching of controversial socio-scientific issues to secondary school students in the age range 14-19. University of London., London.

Lewis, J., \& Leach, J. (2006). Discussion of Socio-scientific Issues: The role of science knowledge. International Journal of Science Education, 28(11), 126787.

Lindahl, M.G. (2009). Ethics or Morals: Understanding Students' Values Related to Genetic Tests on Humans. Science \& Education, 18(10), 1285-311.

Lynch, M. (1982). Closure and disclosure in pre-trial argument. Human studies, 5(1), 285-318.

Marttunen, M. (1997). Electronic Mail as a Pedagogical Delivery System: An Analysis of the Learning of Argumentation. Research in Higher Education, 38(3), 345-63.

Millar, R. (1997). Science education for democracy. In R. Levinson \& J. Thomas (Eds.), Science Today: Problem or Crisis? (pp. 87-101). London: Routledge.

Millar, R., \& Osborne, J. (1998). Beyond 2000: science education for the future. London: King's College London.

Nowell-Smith, P.H. (1954). Ethics. Balitmore: Penguin Books.

OECD. (2006). Assessing, Scientific, Reading and Mathematical Literacy - A Framework for PISA 2006. Paris: OECD.

Patronis, T., Potari, D., \& Spiliotopoulou, V. (1999). Students $\square$ argumentation in decision-making on a socio-scientific issue: implications for teaching. International Journal of Science Education, 21, 745-54

Pouliot, C. (2008). Students' inventory of social actors concerned by the controversy surrounding cellular telephones: A case study. Science Education, 92(3), 54359.

Ratcliffe, M. (1997). Pupil decision-making about socio-scientific issues within the science curriculum. International Journal of Science Education, 19(2), 16782.

Ryder, J. (2001). Identifying Science Understanding for Functional Scientific Literacy. Studies in Science Education, 36(1), 1-44. 
Sadler, T.D. (2004). Informal reasoning regarding socioscientific issues: A critical review of research. Journal of Research in Science Teaching, 41(5), 513-36.

Sadler, T.D. (2006). Promoting discourse and argumentation in science teacher education. Journal of Science Teacher Education, 17(4), 323-46.

Sadler, T.D., \& Donnelly, L. (2006). Socioscientific Argumentation: The effects of content knowledge and morality. International Journal of Science Education, 28(12), 1463-88.

Sadler, T.D., \& Zeidler, D.L. (2003). The morality of socioscientific issues: Construal and resolution of genetic engineering dilemmas. Science Education, 88(1), 427.

Sadler, T.D., \& Zeidler, D.L. (2004). Negotiating Gene Therapy Controversies. The American Biology Teacher, 66(6), 428-33.

Sadler, T.D., \& Zeidler, D.L. (2005a). Patterns of informal reasoning in the context of socioscientific decision making. Journal of Resarch in Science Teaching, 42(1), 112-38.

Sadler, T.D., \& Zeidler, D.L. (2005b). The significance of content knowledge for informal reasoning regarding socioscientific issues: Applying genetics knowledge to genetic engineering issues. Science Education, 89(1), 71-93.

Sadler, T.D., \& Zeidler, D.L. (2006). Scientific Errors, Atrocities and Blunders. In Dana L. Zeidler (Ed.), The Role of Moral Reasoning on Socioscientific Issues and Discourse in Science Education (pp. 261-85). Dordrecht: Springer.

Sampson, V., \& Clark, D. (2008). Assessment of the ways students generate arguments in science education: Current perspectives and recommendations for future directions. Science Education, 92(3), 447-72.

Searle, J.R. (1969). Speech Acts: An Essay in the Philosophy of Language: Cambridge University Press.

Simon, S. (2008). Using Toulmin's Argument Pattern in the evaluation of argumentation in school science. International Journal of Research \& Method in Education, 31(3), 277-89.

Smith, P.C. (1995). Towards a Discursive Logic: Gadamer and Toulmin on Inquiry and Argument. In L. K. Schmidt (Ed.), The Specter of Relativsm (pp. 159-77). Evanston: Northwestern University Press.

Takala, T. (2005). The Many Wrongs of human Reproductive Cloning. In M Häyry, T Takala \& P Herissone-Kelly (Eds.), Bioethics and Social Reality (pp. 53-66). Amsterdam: Rodolpi.

Thomas, D.R. (2003). A General Inductive Approach for Qualitative Data Analysis. Retrieved from http://www.health.auckland.ac.nz/hrmas/Inductive2003.pdf

Toulmin, S.E. (1958). The Uses of Argument. Cambridge: Cambridge University Press.

Trent, J. (1968). Toulmin's model of an argument: An examination and extension. Quarterly Journal of Speech, 54(3), 252-9.

Tseronis, A. (2009). Qualifying standpoints. Stance adverbs as a presentational device for managing the burden of proof. Utrecht: Netherlands Graduate School of Linguistics.

van Eemeren, F.H., \& Grootendorst, R. (1982). The speech acts of arguing and convincing in externalized discussions. Journal of Pragmatics, 6(1), 1-24.

van Eemeren, F.H., \& Grootendorst, R. (1989). Speech act conditions as tools for reconstructing argumentative discourse. Argumentation, 3(4), 367-83.

van Eemeren, F.H., \& Grootendorst, R. (2004). A systematic theory of argumentation: The pragma-dialectical approach. Cambridge: Cambridge University Press. 
van Eemeren, F.H., Grootendorst, R., \& Kruiger, T. (1987). Handbook of Argumentation Theory: a Critical Survey of Classical Backgrounds and Modern Studies. Dordrecht: Foris.

van Eemeren, F.H., \& Houtlosser, P. (2002). Strategic maneuvering with the burden of proof. . In F.H. van Eemeren (Ed.), Advances in pragma-dialectics (pp. 1328). New Port News, VA: Vale Press.

van Eemeren, F.H., \& Houtlosser, P. (2007). The study of argumentation as normative pragmatics. Pragmatics: Quarterly Publication of the International Pragmatics Association, 15(1), 161-77.

van Eemeren, F.H., Houtlosser, P., \& Henkemans, A.F.S. (2007). Argumentative indicators in discourse: a pragma-dialectical study. Dordrecht: Springer.

Walker, K., \& Zeidler, D.L. (2007). Promoting discourse about socioscientific issues through scaffolded inquiry. International Journal of Science Education, 29(11), 1387-410.

Wilkinson, S. (2010). On the distinction between positive and negative eugenics. In M Häyry, T Takala \& P Herissone-Kelly (Eds.), Arguments and Analysis in Bioethics (pp. 115-28). Amsterdam: Rodolpi.

Yin, R.K. (2009). Case Stuy Research. Design and Methods. Thousand Oaks: Sage. Zeidler, D.L., Osborne, J., Erduran, S., Simon, S., \& Monk, M. (2006). The Role of Argument During Discourse About Socioscientific Issues. In Dana L. Zeidler (Ed.), The Role of Moral Reasoning on Socioscientific Issues and Discourse in Science Education (pp. 97-116). Dordrecht: Springer.

Zeidler, D.L., Sadler, T.D., Simmons, M.L., \& Howes, E. (2005). Beyond STS: A research-based framework for socioscientific issues education. Science Education, 89(3), 357-77.

Zohar, A., \& Nemet, F. (2002). Fostering students' knowledge and argumentation skills through dilemmas in human genetics. Journal of Research in Science Teaching, 39(1), 35-62. 